\title{
Effectiveness of Early Hematopoietic Stem Cell Transplantation in Preventing Neurocognitive Decline in Mucopolysaccharidosis Type II: A Case Series
}

\author{
A. Selvanathan • C. Ellaway $\cdot$ C. Wilson $\cdot$ P. Owens \\ P. J. Shaw $\cdot$ K. Bhattacharya
}

Received: 17 May 2017 /Revised: 18 March 2018 / Accepted: 19 March 2018/Published online: 19 April 2018

(C) Society for the Study of Inborn Errors of Metabolism (SSIEM) 2018

\begin{abstract}
The early progressive form of the X-linked disorder, Hunter syndrome or mucopolysaccharidosis type II (MPS II) (OMIM \#309900), is characterized by cognitive decline, and pulmonary and cardiac complications that often cause death before 20 years of age. Deficiency of the lysosomal enzyme, iduronate-2-sulfatase (EC 3.1.6.13) results in deposition of the glycosaminoglycans, dermatan, and heparan sulfate in various tissues. In recent years, enzyme replacement therapy (ERT) has become the mainstay of treatment, but is expensive and ineffective in arresting cognitive decline. Hematopoietic stem cell transplantation (HSCT) also provides enzyme replacement, and may be effective in stabilizing neurocognitive function if initiated early, though data are limited. We present a case series of four patients who demonstrated neurocognitive stabilization with early HSCT. HSCT is a potentially underutilized treatment strategy for select groups of MPS II patients.
\end{abstract}

Communicated by: Verena Peters

A. Selvanathan $\cdot$ C. Ellaway $\cdot$ P. Owens $\cdot$ K. Bhattacharya

Genetic Metabolic Disorders Service, The Children's Hospital at Westmead, Westmead, NSW, Australia

A. Selvanathan $(\bowtie) \cdot$ C. Ellaway $\cdot$ P. J. Shaw $\cdot$ K. Bhattacharya Discipline of Child and Adolescent Health, The University of Sydney, Camperdown, NSW, Australia

e-mail: arthavan.selvanathan@health.nsw.gov.au

C. Wilson

Starship Paediatric Metabolic Service, Starship Children's Hospital, Auckland, New Zealand

P. J. Shaw

Blood and Marrow Transplant Service, The Children's Hospital at Westmead, Westmead, NSW, Australia

\begin{abstract}
Abbreviations
ADL Activities of daily living

ATG Anti-thymocyte globulin

AUC Area Under Curve

CNS Central nervous system

CSF Cerebrospinal fluid

CT Computed tomography

DAS-II Differential Ability Scales, Second Edition

DQ Developmental quotient

ERT Enzyme replacement therapy

HLA Human leukocyte antigen

HSCT Hematopoietic stem cell transplantation

IDS Iduronate-2-sulfatase

IQ Intelligence quotient

MPS Mucopolysaccharidosis

MPS I Mucopolysaccharidosis type I (Hurler syndrome)

MPS II Mucopolysaccharidosis type II (Hunter syndrome)

MRI Magnetic resonance imaging

WISC-IV Weschler Intelligence Scale for Children 4th Edition

WPPSI III Weschler Preschool and Primary Intelligence Scale 3rd Edition
\end{abstract}

Introduction

First described by Charles Hunter (1917) in two brothers with modest intellectual deficit and significant somatic manifestations, Hunter syndrome (OMIM \#309900) was subsequently identified as an X-linked mucopolysaccharidosis (MPS II) characterized by accumulation of two glycosaminoglycans (dermatan and heparan sulfate), due to deficiency of iduronate-2-sulfatase (IDS) (Giugliani 
et al. 2014). The deposition of glycosaminoglycans causes both organ enlargement (hepatosplenomegaly, macroglossia, cardiac valve thickening) and neurocognitive effects. There is a broad spectrum of affected individuals (Neufeld and Menzer 2001).

Treatment for MPS II was initially limited to symptomatic management (Wraith et al. 2008). Enzyme replacement therapy (ERT) was trialed in the early 2000s, with Phase I/ II trials showing marked reduction in urinary glycosaminoglycans, hepatosplenomegaly, and mild improvement in the 6-min walk test (Muenzer et al. 2007). ERT therefore is currently the gold standard treatment of the somatic manifestations of MPS II, but has limited effect on cognitive decline (Muenzer et al. 2007).

Following the initial reports (Hobbs et al. 1981) of allogeneic hematopoietic stem cell transplantation (HSCT) for mucopolysaccharidosis type I (MPS I, or Hurler syndrome, OMIM \#607014) the therapy was extended to children with MPS II. Vellodi et al. (1999) published a series of ten such cases: seven patients died within 100 days post-HSCT, due to graft-versus-host disease and sepsis. Nine of the ten children had neurological involvement prior to HSCT.

However since ERT has become available, much progress has been made in optimizing HSCT for MPS I. Recognition of the importance of busulfan dose for central nervous system (CNS) entry, standardized conditioning, and appropriate donor selection to maximize recipient enzyme activity are all aspects of management in MPS I that are directly transferable to MPS II (Wilkinson et al. 2013; Aldenhoven et al. 2015).

Recent evidence suggests that HSCT may stabilize cognition in patients with MPS II if transplantation occurs promptly. Tanjuakio et al. (2015) noted that those who underwent HSCT early had better preservation of "activities of daily living (ADLs)" than those who underwent HSCT late, as well as those treated exclusively with ERT. Kubaski et al. (2017) reviewed 130 patients and demonstrated that ADL scores related to "movement" and "movement and cognition" were better in HSCT than ERT patients, without formal cognitive testing.

In keeping with this contemporary literature, all patients presenting to the Children's Hospital at Westmead since 2012 with MPS II deemed at risk of neurocognitive decline were considered for HSCT. With lack of availability of ERT in New Zealand, patients presenting with MPS II to Starship Hospital in Auckland were considered for HSCT. Our series demonstrates that children with MPS II who underwent HSCT early in the disease course have preserved neurocognition, based on formal developmental assessments. Given the lack of prevention of neurological sequelae despite ERT, it is important that consideration be given to early HSCT as a treatment option for MPS II.

\section{Method}

Cases of MPS II who underwent HSCT were compiled retrospectively by file review. All four children who were referred to the two centers between January 2012 and June 2014 were selected and consented for HSCT, based on emerging neurocognitive symptoms. Ethics approval was provided by the Sydney Children's Hospital Network Research Ethics and Governance Team (Human Research Ethics Committees Reference Number: CCR2016/09). Informed consent was obtained from all patients' families for medical record review and publication.

\section{Results}

\section{Case 1}

\section{Presentation}

Case 1 , now aged 7 years, initially presented at 3.5 years with rapidly increasing head size and abdominal girth. Brain computed tomography (CT) and magnetic resonance imaging (MRI) showed "innumerable dilated perivascular spaces bilaterally giving a honeycombed-like appearance of the cerebral white matter," suggestive of a mucopolysaccharidosis (Fig. 1). On presentation he was able to run, climb stairs, and form three-word sentences. Intellectual assessment pre-HSCT characterized his ability as Borderline to Low-Average in all domains of the Differential Ability Scales (DAS-II). See Table 1 for IDS enzyme activity and genotype information.

\section{Transplantation}

HSCT was initially attempted at age 3.75 years (Table 2), with no preceding or subsequent ERT. After completing full ablative conditioning with fludarabine and busulfan, he developed severe reactions (fever and rash) after antithymocyte globulin (ATG), and plans for the allograft were aborted. He had autologous cells reinfused and was allowed to recover. He was then reconditioned 3 months later with fludarabine, treosulfan, and alemtuzumab prior to receiving a 7/8 allelic matched unrelated cord blood transplant. He required admission for Epstein-Barr virus reactivation, associated with transient mixed chimerism, with subsequent reversion to fully donor engraftment.

\section{Outcome}

Case 1 continues to walk well 3 years post-HSCT, albeit with mild proximal muscle weakness. When last reviewed at age 7 years, he had started in a mainstream school. His ongoing issues include moderate mixed hearing loss and 


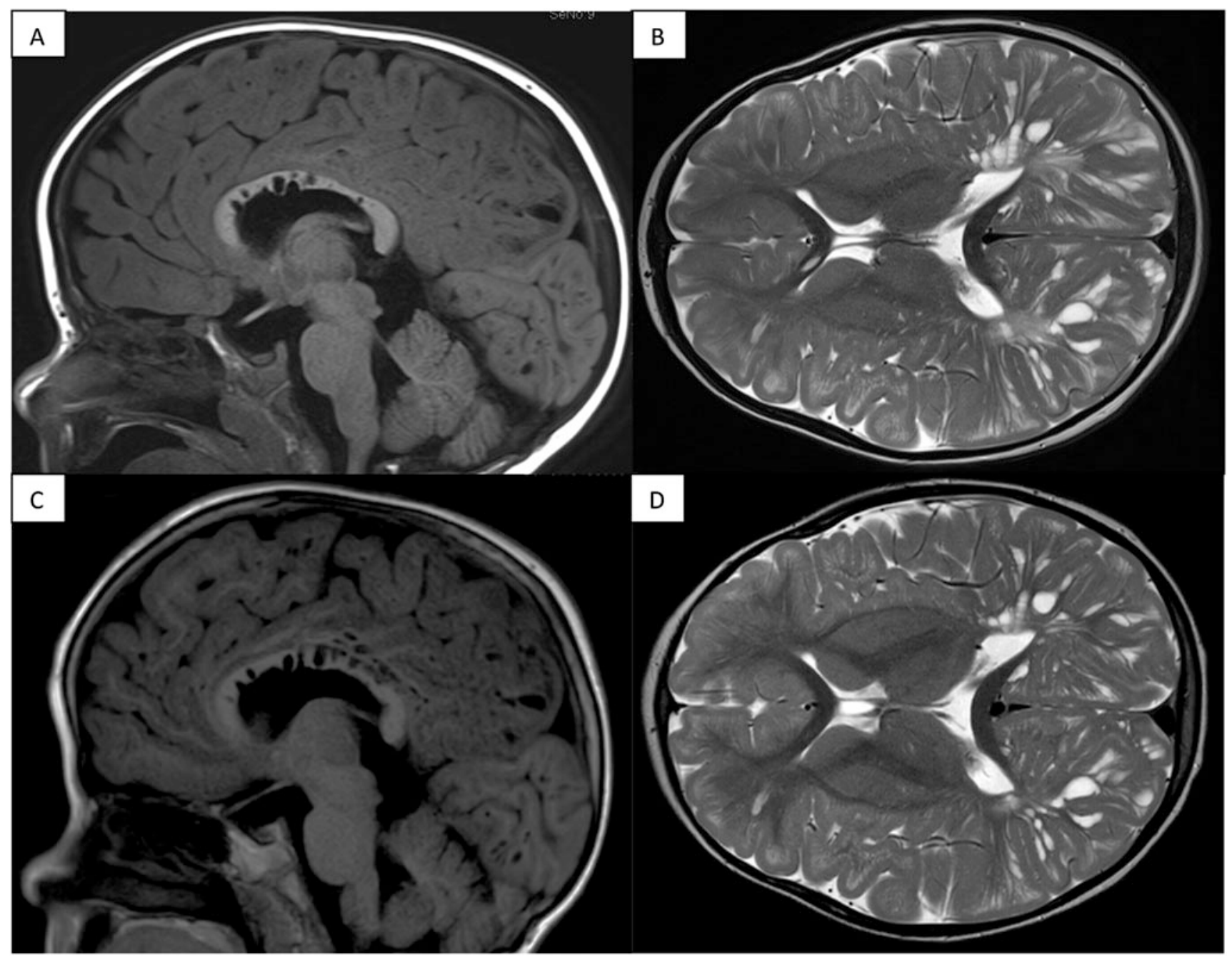

Fig. 1 Brain MRI findings from Case 1, with dilated perivascular spaces: appearances stable 1.5 years post-transplant. T1 FLAIR sagittal (a) and T2 axial (b) sections pre-transplant; with comparable T1 FLAIR sagittal (c) and T2 axial (d) sections post-transplant

difficulty walking up stairs, with upper motor neuron signs (three beats of ankle clonus). A repeat brain MRI at 5.5 years of age (Fig. 1) showed stabilization of the cystic lesions.

\section{Case 2}

\section{Presentation}

This 5-year-old boy was referred by a pediatrician at age 3 years after a hospital admission with a respiratory tract infection, with coarse facial features. His background history included respiratory distress at birth (requiring noninvasive ventilation in intensive care for 3 days), recurrent croup, bilateral hearing loss secondary to recurrent otitis media, speech delay, scoliosis, and thoracolumbar gibbus. He had recently undergone adenoidectomy and insertion of grommets. Developmental assessment preHSCT noted low-average gross motor skills, difficulties with fine motor coordination, poor balance, and disengagement with tasks.

\section{Transplantation}

Case 2 did not receive ERT prior to HSCT. He was conditioned with fludarabine, busulfan, and ATG prior to receiving an $8 / 8$ allelic matched unrelated cord blood transplant at age 3.5 years. He suffered severe mucositis and veno-occlusive disease following the conditioning regimen. His post-HSCT course was complicated by a 3week hospital stay for pneumonia requiring multiple courses of intravenous antibiotics. 
Table 1 Presenting features of all four children with mucopolysaccharidosis type II

\begin{tabular}{|c|c|c|c|c|}
\hline Patient & 1 & 2 & 3 & 4 \\
\hline $\begin{array}{l}\text { Presenting } \\
\text { features }\end{array}$ & $\begin{array}{l}\text { Macrocephaly, } \\
\text { abdominal distension, } \\
\text { coarse facial features, } \\
\text { macroglossia, cardiac } \\
\text { murmur }\end{array}$ & $\begin{array}{l}\text { Speech delay, coarse } \\
\text { facial features, } \\
\text { recurrent } \\
\text { respiratory tract } \\
\text { infections }\end{array}$ & $\begin{array}{l}\text { Coarse facial features, } \\
\text { hepatomegaly, macrocephaly, } \\
\text { hydrocephalus }\end{array}$ & $\begin{array}{l}\text { Macrocephaly, developmental } \\
\text { delay, enlarged adenoids and } \\
\text { tonsils, cardiac murmur, coarse } \\
\text { facial features }\end{array}$ \\
\hline $\begin{array}{l}\text { Age at } \\
\text { presentation }\end{array}$ & 3 years 6 months & 3 years & 8 months & 3 years 8 months \\
\hline $\begin{array}{l}\text { Age at } \\
\text { diagnosis }\end{array}$ & 3 years 6 months & 3 years & 8 months & 4 years 7 months \\
\hline $\begin{array}{l}\text { IDS enzyme } \\
\text { activity } \\
\text { (pmol/min/mg } \\
\text { protein: } \\
\text { normal range } \\
\text { 10-88) }\end{array}$ & 1.8 & 0.26 & 0.03 & 0.4 \\
\hline Genotype & $\begin{array}{l}\text { c. } 692 \mathrm{C}>\mathrm{G} \\
\text { p. } \operatorname{Pro} 231 \mathrm{Arg}\end{array}$ & $\begin{array}{l}\text { c. } 1327 \mathrm{C}>\mathrm{T} \\
\text { p. } A \operatorname{rg} 443^{*}\end{array}$ & $\begin{array}{l}\text { c. } 57 \mathrm{del} \\
\text { p. Val20Ser }\end{array}$ & $\begin{array}{l}\text { c. } 257 \mathrm{C}>\mathrm{T} \\
\text { p. } \text { Pro } 86 \text { Leu }\end{array}$ \\
\hline $\begin{array}{l}\text { Predicted effect } \\
\text { on IDS }\end{array}$ & $\begin{array}{l}\text { Deleterious missense } \\
\text { (highly conserved } \\
\text { residue in the sulfatase } \\
\text { protein domain) }\end{array}$ & $\begin{array}{l}\text { Premature stop } \\
\text { codon }\end{array}$ & Frameshift mutation & $\begin{array}{l}\text { Activates multiple cryptic splice } \\
\text { sites, resulting in aberrantly } \\
\text { spliced transcripts }\end{array}$ \\
\hline Height (centile) & 25 th -50 th & 95th & 50 th & 60 th \\
\hline Weight (centile) & 75th-90th & 90th & 95 th & 90th \\
\hline $\begin{array}{l}\text { Head } \\
\text { circumference } \\
\text { (centile) }\end{array}$ & $>99$ th & 75 th & 90th & $>95$ th \\
\hline Liver size $(\mathrm{cm})$ & 14 & 14.3 & 6 & 10 \\
\hline MRI brain & $\begin{array}{l}\text { "Innumerable dilated } \\
\text { perivascular } \\
\text { spaces...honeycombed } \\
\text { like appearance of the } \\
\text { cerebral white matter" }\end{array}$ & Not performed & $\begin{array}{l}\text { "Extensive but mild prominence of } \\
\text { the perivascular spaces } \\
\text { throughout the white matter," } \\
\text { abnormal high white matter } \\
\text { signal in occipital lobes, age- } \\
\text { appropriate myelination }\end{array}$ & $\begin{array}{l}\text { "Extensive white matter changes } \\
\text { in the left frontal lobe with } \\
\text { multiple cyst-like spaces } \\
\text { involving the subcortical white } \\
\text { matter. Enlarged perivascular } \\
\text { spaces in the white matter, } \\
\text { especially the corpus callosum. } \\
\text { White matter volume slightly } \\
\text { reduced but normal signal } \\
\text { return" }\end{array}$ \\
\hline Seep study & Not performed & $\begin{array}{l}\text { Apnea-hypopnea } \\
\text { index } \\
24.5 \text { events } / \mathrm{h}, \\
\text { minimum oxygen } \\
\text { saturation } 93 \%\end{array}$ & $\begin{array}{l}\text { Apnea-hypopnea index } \\
9.9 \text { events/h, minimum oxygen } \\
\text { saturation } 85 \%\end{array}$ & $\begin{array}{l}\text { Infrequent brief desaturations, } \\
\text { otherwise normal }\end{array}$ \\
\hline $\begin{array}{l}\text { Previous } \\
\text { operations }\end{array}$ & Hypospadias repair & $\begin{array}{l}\text { Adenoidectomy, } \\
\text { insertion of } \\
\text { grommets }\end{array}$ & Left inguinal hernia repair & $\begin{array}{l}\text { Tonsillectomy, adenoidectomy, } \\
\text { grommet insertions (twice) }\end{array}$ \\
\hline
\end{tabular}

\section{Outcome}

After these initial obstacles, he improved considerably and 7 months post-HSCT was riding a bike. He had a scoliosis and thoracolumbar gibbus pre-HSCT, for which he wore a spinal brace. He initially had mild speech delay (Table 3) and received speech therapy. He has started mainstream school without assistance. His speech was rated as "low average" on repeat assessment.

\section{Case 3}

\section{Presentation}

This 3.5-year-old boy was referred by his pediatrician at the age of 8 months to a tertiary center for suspected meningitis, when he was found to have a bulging fontanelle. He was noted to have acquired macrocephaly and hepatomegaly (Table 1), but normal development. His 
Table 2 Hematopoietic stem cell transplant details for all four children with mucopolysaccharidosis type II

\begin{tabular}{|c|c|c|c|c|}
\hline Patient & 1 & 2 & 3 & 4 \\
\hline $\begin{array}{l}\text { ERT and } \\
\text { duration }\end{array}$ & None & None & $\begin{array}{l}\text { Yes }(12 \text { weeks pre-first HSCT, } \\
8 \text { weeks post-first HSCT })\end{array}$ & None \\
\hline $\begin{array}{l}\text { Age at } \\
\text { transplant }\end{array}$ & 3 years 9 months & 4 years & 1 year 6 months & 5 years 5 months \\
\hline $\begin{array}{l}\text { HLA } \\
\text { matching }\end{array}$ & $\begin{array}{l}\text { Unrelated cord blood, 7/8 HLA } \\
\text { matched }\end{array}$ & $\begin{array}{l}\text { Unrelated cord } \\
\text { blood, } 8 / 8 \text { HLA } \\
\text { matched }\end{array}$ & $\begin{array}{l}\text { Unrelated cord blood, } 8 / 8 \text { HLA } \\
\text { matched }\end{array}$ & $\begin{array}{l}\text { Noncarrier sibling, } 8 / 8 \text { HLA } \\
\text { matched }\end{array}$ \\
\hline Induction & $\begin{array}{l}\text { Fludarabine/busulfan/ATG, } \\
\text { reconditioned with } \\
\text { fludarabine/treosulfan/ } \\
\text { alemtuzumab }\end{array}$ & $\begin{array}{l}\text { Fludarabine/ } \\
\text { busulfan/ATG }\end{array}$ & $\begin{array}{l}\text { Fludarabine/busulfan/ATG, } \\
\text { reconditioned with fludarabine/ } \\
\text { busulfan/alemtuzumab }\end{array}$ & $\begin{array}{l}\text { Fludarabine/busulfan/ } \\
\text { alemtuzumab }\end{array}$ \\
\hline Maintenance & Cyclosporin, mycophenolate & $\begin{array}{l}\text { Cyclosporin, } \\
\text { mycophenolate }\end{array}$ & Cyclosporin, mycophenolate & Cyclosporin \\
\hline Complications & $\begin{array}{l}\text { Fevers and rash after } \\
\text { conditioning for first HSCT } \\
\text { (autologous cells reinfused) }\end{array}$ & $\begin{array}{l}\text { Mucositis, veno- } \\
\text { occlusive disease, } \\
\text { fevers post-HSCT }\end{array}$ & $\begin{array}{l}\text { Serum sickness (autologous cells } \\
\text { reinfused), then mucositis and } \\
\text { fevers with repeat HSCT }\end{array}$ & $\begin{array}{l}\text { Fever, diarrhea, mucositis. } \\
\text { Rash and peripheral edema } \\
\text { secondary to alemtuzumab }\end{array}$ \\
\hline
\end{tabular}

Table 3 Outcomes for all four children with mucopolysaccharidosis type II

\begin{tabular}{|c|c|c|c|c|}
\hline Patient & 1 & 2 & 3 & 4 \\
\hline Age at last follow-up & 6 years & 5 years & 3 years & 10 years \\
\hline $\begin{array}{l}\text { Pre-HSCT overall } \\
\text { developmental } \\
\text { rating }\end{array}$ & Borderline-low average & Borderline-average & Average & Very low-low average \\
\hline $\begin{array}{l}\text { Last developmental } \\
\text { assessment }\end{array}$ & $\begin{array}{l}2.5 \text { years post-HSCT: } \\
\text { Relative strengths in } \\
\text { working memory and } \\
\text { processing speed (average), } \\
\text { weakness in receptive and } \\
\text { expressive language, } \\
\text { attending mainstream } \\
\text { school }\end{array}$ & $\begin{array}{l}1 \text { year post-HSCT: Mild } \\
\text { speech delay (“low } \\
\text { average"), now } \\
\text { attending mainstream } \\
\text { school without any } \\
\text { assistance }\end{array}$ & Not performed & $\begin{array}{l}4 \text { years post-HSCT: Overall } \\
\text { 1st centile. Verbal } \\
\text { comprehension 2nd centile, } \\
\text { perceptual reasoning 6th } \\
\text { centile, working memory } \\
\text { 3rd centile, processing } \\
\text { speed 4th centile (all } \\
\text { unchanged) }\end{array}$ \\
\hline $\begin{array}{l}\text { Post-HSCT overall } \\
\text { developmental } \\
\text { rating }\end{array}$ & Low average & Not assessed & Average & Borderline \\
\hline Height (centile) & 35 th & 8 th & 54 th & 30th \\
\hline Weight (centile) & 47 th & $83 \mathrm{rd}$ & 46th & 50th \\
\hline $\begin{array}{l}\text { Head circumference } \\
\text { (centile) }\end{array}$ & $>99$ th & Not assessed & Not assessed & 95th \\
\hline Liver size $(\mathrm{cm})$ & 11.6 & 15 & 8 & Not assessed \\
\hline MRI brain & Unchanged from pre-HSCT & Not performed & $\begin{array}{l}\text { No cerebral atrophy, } \\
\text { mild progression of } \\
\text { white matter changes }\end{array}$ & Unchanged from pre-HSCT \\
\hline Ongoing issues & $\begin{array}{l}\text { Mild genu valgum, bilateral } \\
\text { mild tendoachilles } \\
\text { contractures, persistent } \\
\text { clonus }\end{array}$ & $\begin{array}{l}\text { Some restriction in } \\
\text { shoulder movements, } \\
\text { thoracolumbar gibbus, } \\
\text { mild fixed flexion } \\
\text { deformity of hip, mild } \\
\text { speech delay }\end{array}$ & $\begin{array}{l}\text { Moderate bilateral hip } \\
\text { dysplasia (requiring } \\
\text { Pemberton osteotomy } \\
\text { on right), feeding } \\
\text { difficulties, recurrent } \\
\text { ear infections }\end{array}$ & $\begin{array}{l}\text { Developmental delay, hearing } \\
\text { impairment with bilateral } \\
\text { cochlear implants, valvular } \\
\text { abnormalities, mild hip } \\
\text { dysplasia, episodic fecal, } \\
\text { and urinary incontinence }\end{array}$ \\
\hline $\begin{array}{l}\text { IDS enzyme activity } \\
(\mathrm{pmol} / \mathrm{min} / \mathrm{mg} \\
\text { protein: normal } \\
\text { range } 10-88)\end{array}$ & 16.3 & 44 & 53 & Not performed \\
\hline
\end{tabular}


Bayley III Developmental Assessment at 8 months demonstrated scores within the average range for cognition (9), receptive language (8), and fine motor skills (11). Gross motor skills (6) and expressive language (5) were borderline low. His tympanometry studies were suggestive of middle ear dysfunction, worse (moderate-severe) on the left side.

\section{Transplantation}

Case 3 was planned to undergo allogeneic HSCT at age 14 months but like Case 1, became unwell after receiving fludarabine and busulfan for conditioning, as well as ATG. He was infused his autologous backup cells, and conditioning for a second HSCT was performed at age 17.5 months. During this time (from age 11 to 19 months), he received ERT. Repeat Bayley III assessment at 16 months showed some deterioration in gross motor (4), receptive language (5), and fine motor (8) domains, with other domains unchanged.

Case 3 was reconditioned with fludarabine, alemtuzumab, and full-dose busulfan (Area Under Curve, AUC $83.1 \mathrm{mg} / \mathrm{L} \mathrm{h}$ ) for the second HSCT, together with venoocclusive disease prophylaxis with defibrotide. This is because the cumulative exposure to busulfan prior to the first graft (AUC $62.3 \mathrm{mg} / \mathrm{L} \mathrm{h}$ ) was inadequate to achieve optimal brain conditioning (Wilkinson et al. 2013). He received an $8 / 8$ allelic matched unrelated cord blood transplant and his subsequent course was relatively uncomplicated.

\section{Outcome}

There was normalization of IDS activity at age 21 months, or 3 months following the second HSCT (Table 3). At 3.5 years, he is able to express himself in two-word phrases and follow two-step instructions. He has normal gross motor development and can feed himself normally. He awaits formal developmental assessment post-transplant. Orthopedic follow-up 1 year post-HSCT noted moderate bilateral hip dysplasia, and walking difficulties requiring a right-sided Pemberton osteotomy.

\section{Case 4}

\section{Presentation}

Case 4 presented at age 3.5 years to his general pediatrician for assessment of speech delay. His past history included recurrent otitis media and viral respiratory tract infections. He previously had a tonsillectomy and bilateral grommet insertions. A diagnosis of MPS II was made at age 4.5 years and on referral to the metabolic service coarse facial features were noted. Neuropsychiatric assessment using the Weschler Preschool and Primary Scale of Intelligence 3rd Edition (WPPSI III) showed him to have nonverbal reasoning and speed-of-processing skills in the low-average and average ranges for his age respectively (Table 1). His verbal communication was compromised and he was unable to reliably complete any formal assessment tasks.

\section{Transplantation}

Due to his developmental delay, mutation suggesting a severe outcome and the unavailability of ERT in New Zealand, it was decided to proceed to HSCT. He was conditioned with fludarabine, busulfan, and alemtuzumab, and received a full (8/8) allelic matched HSCT from a noncarrier female sibling. He had some mild problems postHSCT with mucositis and an unexplained fever (Table 2), but in general coped well.

\section{Outcome}

Case 4 is now 4 years post-HSCT. He has stable moderate mitral and aortic valve incompetence with normal left ventricular function and bilateral cochlear implants. Ongoing issues (Table 3) include episodic urinary and fecal incontinence. His neuropsychiatric assessments showed an initial deterioration in the year post-HSCT but with stabilization over the following 4 years. His overall development is between the second and fifth centiles as judged by the Weschler Intelligence Scale for Children 4th Edition (WISC-IV). He attends mainstream school with the help of a teacher's aide.

\section{Summary of Cases}

Of the four children with MPS II who underwent HSCT, two attended mainstream school without assistance. The third (a younger child) had below-average gross motor and receptive language domains, but was rated average across the other domains. The final case had neurodevelopmental sequelae prior to HSCT and stabilized after a period of initial deterioration. These cases are in contrast to the natural history of the disorder and that treated with ERT, with neurological regression. These cases also demonstrate the significant risks associated with HSCT, including conditioning reactions and mucositis.

\section{Discussion}

Experience with ERT in MPS II

Over the last decade, the mainstay of MPS II treatment has been ERT with synthetic IDS (Idursulfase) infusions 
(Wraith et al. 2008). There is no evidence of cognitive improvement, except for mild behavioral benefits secondary to reduction in somatic symptoms (Abbott 2013). This is because the synthetic enzyme is a large, antigenic protein that does not cross the blood-brain barrier. Attempts have been made at enhancing CNS penetration, such as intrathecal Idursulfase (Muenzer et al. 2016); preliminary trials have been completed with detailed efficacy data awaited. There is substantial cost involved with treatment and also risks, including intrathecal drug delivery device infection (Cho et al. 2015).

Other challenges of ERT include accessibility for rural patients, development of antibodies, availability (even in tertiary centers as in Case 4), long-term venous access, and significant financial and psychosocial costs of lifelong treatment (Wyatt et al. 2012).

Experience and Benefits of HSCT in the Mucopolysaccharidoses

HSCT has been a key component of the treatment strategy for Hurler syndrome (MPS I) since Hobbs et al. (1981) demonstrated reduction in urinary glycosaminoglycans, corneal clouding, hepatosplenomegaly, and stabilization of neurocognitive function in an 8-month-old post-HSCT. This led to the development of robust HSCT selection criteria for Hurler syndrome patients, namely: children under age 2 years, cognitively intact (developmental quotient, DQ > 70), and genotype suggestive of a severe phenotype (Muenzer et al. 2009). Subsequently in a case series of 31 patients, it was demonstrated that HSCT at an even younger age led to essentially normal development (Poe et al. 2014).

The mechanism of this neurocognitive stabilization in Hurler syndrome may be related to HSCT increasing CNS penetration of enzyme. Effective myeloablation prior to transplantation results in accelerated microglia turnover in mice studies and a CNS environment in which donorderived stem cells cross the blood-brain barrier and differentiate into microglia (Capotondo et al. 2012). These microglia then secrete enzyme in the CNS and prevent accumulation of glycosaminoglycans. This engraftment and production of enzyme also occur in the human brain posttransplantation (Araya et al. 2009). The choice of conditioning is critical. Busulfan achieves better microglial engraftment than irradiation or treosulfan (Capotondo et al. 2012) and the dose of busulfan is important in achieving effective myeloablation (Wilkinson et al. 2013).

Currently there is uncertainty regarding the role of HSCT in MPS II. Small studies have demonstrated significant improvement in non-neurocognitive outcomes. In eight patients who underwent HSCT with longer-term follow-up (over 6 years), there was normalization of urinary glycosaminoglycans in six patients, with resolution of hepatosplenomegaly, improvement in facial features, and lack of cardiac deterioration in all patients (Guffon et al. 2009). Comparative studies between HSCT and ERT suggest that both lead to similar improvement in growth compared to untreated patients (Patel et al. 2014).

HSCT however did not prevent neurocognitive deterioration for some patients. In four patients with intelligence quotient (IQ) below 80 pre-HSCT, IQ dropped to below 50 in all cases at last follow-up (Guffon et al. 2009). Nonetheless, busulfan doses used in these cases were lower than current practice and two had carrier sibling donors. If evidence from Hurler syndrome is extrapolated (Aldenhoven et al. 2015), enzyme level post-HSCT is critically important in outcome.

There is some evidence that HSCT performed in the appropriate patient can result in positive neurocognitive outcomes. Tanaka et al. (2012) retrospectively reviewed records of 21 patients who underwent HSCT and noted that transplantation appeared to be effective in preventing neurological deterioration, but only in patients without developmental delay pre-HSCT. Those with preexisting category IV lesions on their brain MRI (suggesting significant neuronal loss) had worsening of their outcomes. Tanjuakio et al. (2015) studied four groups of patients (early and late ERT, and early and late HSCT), with late ERT defined as after age 8 years, and late HSCT defined as after age 5 years. The early HSCT group had the highest scores in the ADL questionnaire. Similar findings were noted by Kubaski et al. (2017), with the best scores in "movement" and "movement with cognition" belonging to those who had undergone HSCT early.

Novel modifications to transplantation for the mucopolysaccharidoses are currently being developed, including lentiviral transduction ex vivo to overexpress enzyme within cells for subsequent autologous transplantation (Langford-Smith et al. 2012). This would eliminate risk of graft-versus-host disease, and the approach is awaiting clinical trial for mucopolysaccharidosis type III (OMIM \#252900). Given the recent validation of an IDS-knockout mouse model for MPS II (Gleitz et al. 2017), a similar methodology could be trialed in animal models for MPS II in the future.

\section{Our Experience with HSCT in MPS II}

Our case series adds to the literature demonstrating the benefit of early HSCT in MPS II. In patients where neurocognitive decline appears likely or where ERT is unavailable, HSCT remains the only therapy for neurocognitive stabilization. All our four cases demonstrate this, with three showing neurocognitive, as well as somatic, improvement. 
Case 4 had clinical and radiological evidence of neurocognitive impairment pre-HSCT, with developmental delay particularly in receptive language. Nonetheless, following HSCT his development has stabilized in the borderline range (2nd-5th centile) on the WISC-IV, with the MRI appearance of the brain also unchanged.

Cases 1 and 2 on the other hand, who underwent HSCT at a younger age, both attend a mainstream school with no additional supports. In patients with the severe MPS II phenotype, ERT has not demonstrated such stabilization of neurocognitive function. We propose early HSCT as a viable treatment alternative.

\section{Challenges of HSCT}

There has been a significant reduction in mortality and morbidity from HSCT in inborn errors of metabolism. European data for Hurler syndrome shows that event-free transplant survival has drastically improved, from $58 \%$ at 3 years from 1994 to 2004 data to $91 \%$ in 2005 to 2008 data (Boelens et al. 2010). The Australian Bone Marrow Transplant Recipient Register lists the 1-year mortality for children who underwent HSCT for metabolic disorders in Australia and New Zealand as 16.7\% (I. Nivison-Smith, Australasian Bone Marrow Transplant Recipient Registry, personal communication, May 10, 2017). This reduction in mortality is primarily due to more effective conditioning regimens, reducing mixed chimerism and other causes of graft failure (Boelens et al. 2007). Similar MPS II-specific data are not present in the literature to-date.

Morbidity is nonetheless still considerable. In two of our cases, there were unexpected toxicities and autologous cell reinfusion in the initial instance. All patients have ongoing musculoskeletal problems, which are not corrected with the enzyme penetration achieved with either ERT or HSCT (Desnick and Schuchman 2012). Consequences of conditioning can be lifelong, such as infertility with gonadotoxic myeloablative regimens (Tichelli and Rovo 2013).

\section{Limitations of Our Case Series}

One key limitation to our study is the varying pre-HSCT patient baselines. This reflects the varying genotypes and phenotypes of MPS II, with later presentation than MPS I. It is difficult to draw any significant conclusions regarding the appropriate age for HSCT, or the degree of pre-HSCT neurocognitive deficit considered acceptable. But early consideration of HSCT should produce results at least as favorable as ERT, and we hope that adding to the literature will encourage larger studies to answer these questions.

\section{Conclusion}

ERT ameliorates most somatic manifestations of MPS II, but there is no evidence for improving neurocognitive improvement. There are also considerable social and financial burdens associated with lifelong treatment. Lessons learned from MPS I have reduced HSCT-related mortality and morbidity. Our case series contributes to the growing literature suggesting that HSCT may stabilize neurocognition in MPS II patients when undertaken early in the disease course. Larger case control or cohort studies are required to determine the most appropriate age for HSCT, which mutations suggest the need for early HSCT, and standardized tools to assess neurocognitive outcomes post-HSCT.

\section{Synopsis}

Hematopoietic stem cell transplantation is an under-recognized but effective therapy that stabilizes neurocognitive function in patients with mucopolysaccharidosis type II.

\section{Contributions of Authors}

Arthavan Selvanathan: planning of project, retrieving and analyzing files, performing literature review, creating initial draft of the chapter, editing the chapter, submission process, correspondence with journal.

Carolyn Ellaway: planning of project, submission of ethics approval, clinical management of patients, analyzing files, editing the chapter.

Callum Wilson: clinical management of patients, analyzing medical records, editing the chapter.

Penny Owens: clinical management of patients, editing the chapter.

Peter Shaw: planning of project, clinical management of patients, analyzing files, editing the chapter.

Kaustuv Bhattacharya: planning of project, clinical management of patients, analyzing files, editing the chapter.

\section{Compliance with Ethics Guidelines}

Ethics approval was granted by the Sydney Children's Hospital Network Research Ethics and Governance Team (HREC Reference Number: CCR2016/09). All procedures followed were in accordance with the ethical standards of the responsible committee on human experimentation (institutional and national) and with the Helsinki Declaration of 1975, as revised in 2000. Informed consent was obtained from all patients' families in order to review medical records, and publish their cases anonymized. 


\section{Correspondence and Statement of Competing Interests}

I, Arthavan Selvanathan, serve as corresponding author and guarantor for this chapter. None of the authors have received or accepted reimbursements or funding in relation to the material in this chapter.

All authors (Arthavan Selvanathan, Carolyn Ellaway, Callum Wilson, Penny Owens, Peter Shaw and Kaustuv Bhattacharya) declare they have no conflicts of interest.

Competing Interests: None declared.

\section{References}

Abbott J (2013) Blood-brain barrier structure and function and the challenges for CNS drug delivery. J Inherit Metab Dis 36 (3):437-449

Aldenhoven M, Wynn R, Orchard P et al (2015) Long-term outcome of Hurler syndrome patients after hematopoietic stem cell transplantation: an international multicenter study. Blood 125 (13):2164-2172

Araya K, Sakai N, Mohri I et al (2009) Localized donor cells in brain of a Hunter disease patient after cord blood stem cell transplantation. Mol Genet Metab 98(3):255-263

Boelens J, Wynn R, O'Meara A et al (2007) Outcome of hematopoietic stem cell transplantation for Hurler's syndrome in Europe: a risk factor analysis for graft failure. Bone Marrow Transplant 40:225-233

Boelens J, Prasad V, Tolar J et al (2010) Current international perspectives on hematopoietic stem cell transplantation for inherited metabolic disorders. Pediatr Clin N Am 57:123-145

Capotondo A, Milazzo R, Politi L et al (2012) Brain conditioning is instrumental for successful microglia reconstitution following hematopoietic stem cell transplantation. Proc Natl Acad Sci U S A 109(37):15018-15023

Cho S, Lee J, Ko A et al (2015) Effect of systemic high dose enzyme replacement therapy on the improvement of CNS defects in a mouse model of mucopolysaccharidosis type II. Orphanet J Rare Dis 10:141-152

Desnick R, Schuchman E (2012) Enzyme replacement therapy for lysosomal diseases: lessons from 20 years of experience and remaining challenges. Annu Rev Genomics Hum Genet 13:307-335

Giugliani R, Villareal M, Valdez C et al (2014) Guidelines for diagnosis and treatment of Hunter syndrome for clinicians in Latin America. Genet Mol Biol 37(2):315-329

Gleitz H, O'Leary C, Holley R et al (2017) Identification of agedependent motor and neuropsychological behavioural abnormalities in a mouse model of mucopolysaccharidosis type II. PLoS One 12(2):e0172435

Guffon N, Bertrand Y, Forest I et al (2009) Bone marrow transplantation in children with Hunter syndrome: outcome after 7 to 17 years. J Pediatr 154:733-737

Hobbs J, Barrett A, Chambers D et al (1981) Reversal of clinical features of Hurler's disease and biochemical improvement after treatment by bone marrow transplantation. Lancet 318 (8249):709-712

Hunter C (1917) A rare disease in two brothers. Proc R Soc Med 10:104-116

Kubaski F, Suzuki Y, Yabe H et al (2017) Hematopoietic stem cell transplantation for patients with mucopolysaccharidosis type II. Mol Genet Metab 120(1-2):S77

Langford-Smith A, Wilkinson F, Langford-Smith K et al (2012) Hematopoietic stem cell and gene therapy corrects primary neuropathology and behaviour in mucopolysaccharidosis IIIA mice. Mol Ther 20(8):1610-1621

Muenzer J, Gucsavas-Calikoglu M, McCandless S et al (2007) A phase I/II clinical trial of enzyme replacement therapy in mucopolysaccharidosis II (Hunter syndrome). Mol Genet Metab 90:329-337

Muenzer J, Wraith J, Clarke L et al (2009) Mucopolysaccharidosis I: management and treatment guidelines. Pediatrics 123(1):19-29

Muenzer J, Hendriksz C, Fan Z et al (2016) A phase I/II study of intrathecal idursulfase-IT in children with severe mucopolysaccharidosis II. Genet Med 18(1):73-81

Neufeld E, Menzer J (2001) The mucopolysaccharidoses. In: Scriver C, Beaudet A, Sly W, Valle D et al (eds) The metabolic and molecular bases of inherited disease, vol 3, 8th edn. McGrawHill, New York, pp 3421-3452

Patel P, Suzuki Y, Tanaka A et al (2014) Impact of enzyme replacement therapy and hematopoietic stem cell therapy on growth in patients with Hunter syndrome. Mol Genet Metab Rep $1: 184-196$

Poe M, Chagnon S, Escolar M (2014) Early treatment is associated with improved cognition in Hurler syndrome. Ann Neurol 76 (5): $747-753$

Tanaka A, Okuyama T, Suzuki Y et al (2012) Long-term efficacy of hematopoietic stem cell transplantation on brain involvement in patients with mucopolysaccharidosis type II: a nationwide survey in Japan. Mol Genet Metab 107:513-520

Tanjuakio J, Suzuki Y, Patel P et al (2015) Activities of daily living in patients with Hunter syndrome: impact of enzyme replacement therapy and hematopoietic stem cell transplantation. Mol Genet Metab 114:161-169

Tichelli A, Rovo A (2013) Fertility issues following hematopoietic stem cell transplantation. Expert Rev Hematol 6(4):375-388

Vellodi A, Young E, Cooper A (1999) Long-term follow-up following bone marrow transplantation for Hunter disease. J Inherit Metab Dis 22:638-648

Wilkinson F, Sergijenko A, Langford-Smith K, Malinowski M, Wynn R, Bigger B (2013) Busulfan conditioning enhances engraftment of hematopoietic donor-derived cells in the brain compared with irradiation. Mol Ther 21(4):868-876

Wraith J, Scarpa M, Beck M et al (2008) Mucopolysaccharidosis type II (Hunter syndrome): a clinical review and recommendations for treatment in the era of enzyme replacement therapy. Eur J Paediatr 167:267-277

Wyatt K, Henley W, Anderson L et al (2012) The effectiveness and cost-effectiveness of enzyme and substrate replacement therapies: a longitudinal cohort study of people with lysosomal storage disorders. Health Technol Assess 16(39):1-543 